\title{
ACCESSIBILITY AS A KEY MANAGEMENT COMPONENT OF THE PARALYMPICS
}

\section{SIMON DARCY}

\section{Please cite as:}

Darcy, S. (2017). Accessibility as a key management component of the Paralympics. In S. Darcy, S. Frawley \& D. Adair (Eds.), Managing the Paralympics (pp. 47-90). Basingstoke, Hampshire: Palgrave Macmillan. 


\section{INTRODUCTION}

The Paralympics are undoubtedly the pinnacle sporting event for people with disability where accessibility is both a facilitator of the event and a potential legacy of the event. Accessibility is so ubiquitous to contributing to legacy yet the operationalisation of accessibility has been so poorly understood globally that the UN Convention on the Rights of Persons with Disabilities (CRPWD) has placed it central to the preamble in "recognising the importance of accessibility to the physical, social, economic and cultural environment, to health and education and to information and communication" (United Nations, 2006, p. np). In doing so, the CRPWD recognises accessibility as the enabler for people with disability enjoying citizenship. Similarly, accessibility at the Paralympic games has had a history of being considered the best they could do rather than on the cutting edge of accessibility for most of its early years. The informal convergence of the Olympic and Paralympic Games from Barcelona 1992 raised significant issues for disability access in host cities Gold and Gold (2007). Although the requirement to run the two events together only really became binding with the 2008 Beijing Games, from 1992 potential hosts with an established record of upholding disability rights and legislation had a clear advantage in the bidding process that raised the expectations that the Paralympics would be incorporated with the highest level of accessibility.

Accessibility goes well beyond the magnificent and at times overly costly sport venues that are the stage upon which the athletes perform at Olympic and Paralympic games to the mundane engineering and building codes and standards that must be seamlessly integrated within all levels of planning, infrastructure and operational logistics for both the Olympics and Paralympics to be a success (Darcy \& Harris, 2003). For the Paralympics accessibility is essential for the 5000 athletes and unknown number of employees, subcontractors, volunteers and spectators with disability to arrive, engage and depart from the games. From the host city perspective the end of the games is the beginning of what should be considered the legacy phase as thoroughly examined by Laura Misener in Chapter 4 (Misener, 2017). The legacy phase and the leveraging of community inclusion, disability events more broadly and accessible tourism offer the potential for ongoing benefits economically, socially and from a destination image perspective (Dickson, Misener, \& Darcy, in press). Yet, that potential arising from the "accessibility of the games” to keep on giving after the games are long forgotten requires a considered approach to the urban environment, facilitating transport infrastructure, creativity amongst those in power to encourage commercial opportunities, not-for-profit social enterprises and visionary marketing of place and space (Gold \& Gold, 2010).

For Gold and Gold's (2010) vision for a sustainable legacy to occur, policy makers and other stakeholders need to be convinced of the wider benefits of accessibility as it contributes to sustainability for groups other than those with disabilities. As Darcy and Dickson (2009) suggest, 31\% 
of the population benefit from inclusive planning for tourism and events. The $31 \%$ includes those who may have a temporary disability, those families with young children who use strollers, older people who don't identify as having a disability, and those who travel with a companion. With games planning including universal design criteria, further beneficiaries are anyone working on a site who will benefit from a safer working environment (e.g. Anyone delivering goods and emergency personnel), travellers who have heavy luggage and those who are from language groups other than the dominant language discourse (e.g. wayfinding signage including universal iconography). It explicitly identifying universal design as a core component of the guidelines, the IPC has effectively moved beyond just providing access for participating athletes. As the main definition of universal design states:

"Universal design is the design of products and environments to be usable by all people, to the greatest extent possible, without the need for adaptation or specialized design. The intent of the universal design concept is to simplify life for everyone by making products, communications, and the built environment more usable by more people at little or no extra cost. The universal design concept targets all people of all ages, sizes and abilities'. The Universal Design approach goes beyond traditional design, which tends to focus on the “average” user. Universal Design is a design approach, reflecting a way of understanding people's needs. It is not a list of particular solutions, measurements, or products. - Universal Design is the way to reach the solution, contributing to social inclusion". (cited in Center for Universal Design, 2009; and first articulated by Mace, 1985)

The guidelines reinforce this by including wheelchair users, people who have other mobility impairments, those with vision impairments or who are blind, those who are hard of hearing or who are deaf, those with intellectual impairments and those with psychological impairment. While worker uses, people with other mobility impairments, vision and intellectual impairments are specifically identified as "eligible impairments", the guidelines are far broader in their inclusion spectrum to cover all groups defined in the CRPWD "include those who have long-term physical, mental, intellectual or sensory impairments which in interaction with various barriers may hinder their full and effective participation in society on an equal basis with others” (United Nations, 2006, p. np). This definition also recognises social construction of "disability" as the product of barriers that hinder people with impairment's participation in society. As such, the guidelines promote the importance of equity, dignity and functionality as the fundamental principles for an accessible and inclusive games (IPC 2015, p 19).

While Barcelona and Sydney provided positive, but ad hoc, cases for how this could be achieved (Domínguez, Darcy, \& Alén, 2014; Legg \& Gilbert, 2011) there is an inefficiency in hoping that bidding and host cities would individually understand the importance of the opportunities that hosting a Paralympics offer due to the differences in approach to both access and disability as well as differences in facilitating legalisation in each country. To move from an ad hoc to a strategic approach to accessibility, in the lead up to Beijing 2008 the International Paralympic committee (IPC) realised that together with the Candidature Acceptance Procedure document (International Olympic 
Committee, 2011) for bidding cities that they needed to develop an accessibility guide to developing an inclusive approach to accessibility for the Olympic and Paralympic games (International Paralympic Committee, 2009a, 2013b). The IPC rationale was that the recognition and development of the accessibility guide would elevate accessibility from a consideration to an integrated opportunity for host cities to build upon the knowledge transfer of those cities who have hosted the games previously and the global knowledge base of contemporary accessibility practice. Of course, whether this occurs is another matter for researchers to investigate. The knowledge base of the accessibility guide then needs to be contextualised through each host city developing a detailed accessibility technical guidelines for their cultural context as shown by the Sochi 2014 Winter, Rio 2016 Summer and Pyeong Chang 2018 Winter games (e.g.International Paralympic Committee, 2015b; Rio 2016 Organising Committee for the Olympic and Paralympic Games, 2014; Sochi 2014 Organizing Committee, 2014).

Of course, accessibility needs to be seen in context to the history of the games that has been briefly outlined in the introduction to this book (Darcy, Frawley, \& Adair, 2016). In understanding the historical context that regarded accessibility as a secondary consideration to establishing a major disability sport event, the chapter then focuses on the key contemporary issues in managing accessibility issues of the Paralympics. In doing so, the accessibility considerations for bidding and host cities are outlined as per the IPC Accessibility Guide (2013) but with a value-added understanding that the increased accessibility of the host city becomes an infrastructural legacy postgames. Historical documents from host cities, academic and social critiques of accessibility and other source documentation provide the basis for these discussions. The policy process, role of accessibility within sport venues, the village, transportation, the host city experience, attitudes to disability are discussed before presenting a short case study on London 2012.

\section{Policy Framework and Processes}

The IPC have identified a number of clear objectives for the legacy of the Paralympics movement. Within these official objectives it is clearly stated that IPC "aims to use the Paralympics Games as a vehicle to stimulate social development and leave a long-term sporting and social legacy with the host country” (International Paralympic Committee, 2013a, p. 7). Without access it is difficult for people with disabilities to feel they are fully involved with their community. Consequently, the IPC’s strategy for accessibility goes beyond simply Games’ related infrastructures. The principles, solutions and practices used to make the Host City and all Games-related infrastructure and services accessible and inclusive 'will create a culture of inclusion, which will then influence and change in the long-term the way public facilities and services are designed, operated and delivered' (International Paralympic Committee, 2013a, p. p.7). 
For this reason the accessibility to venues and transport throughout the period of the Olympics and Paralympics games is a key component of the planning of the Games. The IPC initially found that there was a lack of internationally accepted standards for accessibility in public venues that had caused inconsistency in the way Games’ facilities were built and operated. Frequently, national minimum standards or local building codes were used; but, as is usually the case all over the world, minimum standards usually provide for minimum access (International Paralympic Committee, 2013a). In 2006, the IPC established an 'Accessibility Working Group', bringing together experts from different parts of the world, to develop an Accessibility Guide, which would have the dual role of:

- Respond to the need of the host cities’ of Olympic and Paralympic Games (thereafter "The Games") to have a comprehensive set of standards to follow when designing venue and services. In addition, the Guide should respond to the enhanced requirements created by the scope of the Paralympic Games, an event with excessive demand on accessibility than any other event in the world.

- Create a benchmark on accessibility for a global audience. Today, many parts of the world have insufficient legislation, building codes and established practices in this field (International Paralympic Committee, 2009a, p. 7).

Within the broader context of the IPC seeking to stimulate social development, create legacy opportunities in sport and the social context of the host country, there was a very practical consideration for the development and inclusions within the accessibility guide as outlined in Table 1. Generally there is a lack of an international standard for accessibility globally. When this is seen in context of the IPC and accessibility, there is also been a lack of knowledge transfer that has produced an inconsistency in access at Olympic and Paralympic games (Blackman, Dickson, \& Benson, 2016). Further, the IPC wanted to move beyond "minimum standards". With the work of the IPC accessibility working group in 2006 they brought together a Delphi group to set aspirational accessibility standards for venues and services as the Paralympics as an event had the potential to test the boundaries of inclusion more so than any other event in the world. This was due to the 10 types of impairment included, the multisport nature of the event and the global media focus (Brittain, 2010). By having benchmark accessibility standards and an international media focus, it was hoped to lead those parts of the world who currently have insufficient leadership, legislation, codes and standards in the field. By creating a consensus document that is "internationally accepted" the IPC are seeking universal best practice in design and service provision that seeks to promote the Equity, dignity and functionality of people with disability (International Paralympic Committee, 2013, p18). The guide recognises the importance of the technical approach but identifies that the local organising committee, the cultural context and a commitment to ongoing consultation is essential for a commitment to 
universally design for all. It is with this background that we will examine the core components to design and service provision for venues, the village, transport and destination approaches to accessibility by the IPC, host city, OCOG and their stakeholders (Dowling \& Legg, 2017; Peters, Frawley, \& Favaloro, 2017). As discussed, in many parts of the world there are no internationally accepted guidelines but Standards Australia's access and mobility guidelines (Standards Australia, 2009) have been internationally recognised as leading the world in disability and accessibility with an Australian access consultant appointed to the IPC to lead the development of the guidelines and undertake liaison with bidding and host cities (see Darcy \& Appleby, 2011). For the purposes of illustration, the Australian Standards ${ }^{1}$ diagrams are used and where appropriate form the basis of critique areas of deficiency within the IPC guidelines (Standards Australia, 2009).

The guide aims to influence the development of both Games venues and also the transport infrastructure of the host city to ensure that disability access extends beyond simply the venues themselves. Unfortunately the document is simply a 'guide' and while much work is often done for the Olympic infrastructure it does not always extend beyond the venues as required for full participation. What value is access to the venues if there is limited disability access throughout the host city itself? This question has been raised with particular reference to Rio 2016 (Fox, 2015). Each Olympic host city does now develop their own 'Accessibility Manual' in the early stages of planning for the games, using the IPC Guide for development. The Sochi 2014 Organizing Committee for the Winter games “barrier-free” guide (Sochi 2014 Organizing Committee, 2014), Rio 2016 Olympic Committee produced their accessibility guide (Rio 2016 Organising Committee, 2014) and the Pyeong Chang 2018 Organising Committee released their guide for the Winter Olympics and Paralympics early in 2015 (International Paralympic Committee, 2015b)

Brazil generally and Rio de Janeiro, have particular challenges when it comes to the socio economic gap between rich and poor, general accessibility of the urban environment and lack of an inclusive public transport system (Motte-Baumvol \& Nassi, 2012; Santos \& Ribeiro, 2013; Szwarcwald, Andrade, \& Bastos, 2002). Media commentary on access in Rio appears quite positive, with the Mayor of Rio launching a project to improve accessibility throughout the city of Rio in the year before the games (Rio 2016 Organising Committee, 2015). This 'Accessible Routes Project' has been praised by the IPC President, Sir Phillip Craven, where works will focus on key tourist locations throughout the city and will involve improvements to pavements and resurfacing (International Paralympic Committee, 2015a) although many remain cynical (Fox, 2015). The IPC 'family' also get to experience any host city as VIPs whereas those visiting outside of games time or as spectators during the games have a very different experience. A cautionary note about Rio is that at the time of

\footnotetext{
${ }^{1}$ For copyright purposes diagrams representing the Australian Standards have been used with notation in the text identifying any variation from the IPC Accessibility Guidelines.
} 
writing this chapter the President of Brazil has been impeached, and it is unclear how the changing political and social context may impact the delivery of an accessible event or legacy.

Outside of the IPC Accessibility Guide (International Paralympic Committee, 2009b, 2013b), the Candidate Acceptance Procedure document lists some 39 supplementary documents to assist bid cities in preparing their bid (International Olympic Committee, 2011). Many of the technical documents have direct and indirect relevance for venue planning and management. However, not all technical manuals are publicly available due to IOC commercial-in-confidence agreements. These include the Technical Manual on Design Standards for Competition Venues, the Technical Manual on Venues, and the Guide on Environmental Management. The remainder of the chapter uses the available documents and other pertinent sources to guide the discussion.

Table 1: IPC Accessibility Guide Overview

\begin{tabular}{|c|c|}
\hline Chapter & Key components \\
\hline $\begin{array}{l}\text { "Chapter } 1 \\
\text { Introduction }\end{array}$ & $\begin{array}{ll}\text { - } & \text { Mission, Objectives and the Role of the guide } \\
\text { - } & \text { UN Convention on the Rights of Persons with a Disability } \\
\text { - } & \text { Fundamental Principles of Accessibility and Inclusion } \\
\text { - } & \text { Requirements for Creating an Accessible and Inclusive Olympic and Paralympic Games } \\
\text { - } & \text { Beneficiaries of an Accessible and Inclusive Environment } \\
\text { - } & \text { Equitable Games’ Experience for All Constituent Groups }\end{array}$ \\
\hline $\begin{array}{l}\text { Chapter } 2 \\
\text { Technical } \\
\text { Specifications }\end{array}$ & $\begin{array}{l}\text { - } \quad \text { Access and Circulation (pathways and circulation areas, ramps, stairways, surfaces paving and finishes, furniture counters } \\
\text { \& service areas, entrances \& exits, doors \& always, elevated \& escalators, emergency provisions) } \\
\text { - } \quad \text { Amenities (venue seating, washrooms, showers bars \& changing rooms) } \\
\text { - Hotels and Other Accommodations (accessible guestrooms, wheelchair friendly guestrooms, other services within } \\
\text { accommodations sites) } \\
\text { - } \quad \text { Publications and Communications (publications, websites standards, telecommunications, signage, assistive hearing aids) } \\
\text { - Transportation Means (road, rail, air, maritime) }\end{array}$ \\
\hline $\begin{array}{l}\text { Chapter } 3 \\
\text { Training for } \\
\text { Accessibility }\end{array}$ & $\begin{array}{ll}- & \text { Disability Etiquette/Awareness Training } \\
\text { - } & \text { Games/Job Specific Training on Accessibility } \\
- & \text { Venue Specific Training on Accessibility } \\
\end{array}$ \\
\hline $\begin{array}{l}\text { Chapter } 4 \\
\text { Games } \\
\text { Requirements }\end{array}$ & $\begin{array}{l}\text { - Coordination Structures and Timeline for Accessibility (consultation for venue construction, consultation for accessible } \\
\text { operations, coordination with public agencies for accessibility) } \\
\text { - Games Infrastructure (competition venues, Olympic and Paralympic villages, noncompetition venues) } \\
\text { - Functional Areas Considerations on Operations (accommodation, accreditation, airport operations, broadcasting, } \\
\text { opening and closing ceremony, city operations, classification, cleaning and waste, communications, catering, human } \\
\text { resources, image and identity, doping control, event Services, medical services, medal ceremonies \& sports presentation, } \\
\text { licensing-merchandising-retail operations, NAC/NBC relations, Olympic and Paralympic family Services, overlays \& site } \\
\text { management, press operations, rate card, risk management, security, sport, technology, ticketing, transport, venue } \\
\text { operations, village operations, torch relay, mobility services (games mobility) }\end{array}$ \\
\hline $\begin{array}{l}\text { Chapter } 5 \\
\text { The Journey } \\
\text { to an } \\
\text { Accessible } \\
\text { and Inclusive } \\
\text { Host City and } \\
\text { Games }\end{array}$ & $\begin{array}{ll}\text { - } & \text { Transport (definition and scope of accessible transport, types of accessible transport, operations for accessible transport) } \\
\text { - } & \text { Public Services and Facilities (pathway/sidewalks and connecting routes, city parks and outdoor recreation areas, retail } \\
\text { and small goods \& beverage outlets, signage and wayfinding, emergency systems \& response, information provision) } \\
\text { - } \quad \text { Tourism (accommodation \& hotel services, restaurant access, tourist information, sightseeing tours \& tourist points of } \\
\text { interest, attractions \& interior spaces) } \\
\text { - } \quad \text { Culture, Entertainment and Leisure (definitions \& scope, types of accessible culture, entertainment and leisure) } \\
\text { - } \quad \text { Sport (principles and types of access to sport, considerations for integration in mainstream sport activities) } \\
\text { - } \quad \text { Education (accessibility of educational facilities, adapted curriculums, assessment methods and teaching materials) } \\
\text { - }\end{array}$ \\
\hline Appendix & $\begin{array}{ll} & \text { Key measurement reference table } \\
\text { - } & \text { Event accessibility checklist” }\end{array}$ \\
\hline
\end{tabular}

Source: IPC Accessibility Guide (International Paralympic Committee, 2009b, 2013b)

With the advent of the first version of the IPC Accessibility Guidelines (2009), there was a conscious effort to integrate IPC approaches with the UN Convention on the Rights of Persons with Disabilities (United Nations, 2006) that had been established in 2006. Since that time, the CRPWD has been signed by over 160 nations and provides a foundation for nation states to document and report on their inclusion of people with disability across all areas of disability citizenship. Article 30 
specifically identifies sport as part of a rich cultural life. However, Article 30 needs to be seen in context to the underlying principles and other articles that are interdependent and overlapping in their support of human rights approaches to people with disability (Darcy \& Taylor, 2009). Human rights considerations with Paralympic games predate the CRPWD with Ozdowski (2004) explaining with respect to the Sydney 2000 Olympic and Paralympic games, that international humans rights conventions provide a strong case for people with disabilities to be provided with access and inclusion in society as part of their existing human rights. He also indicates that while in many countries substantial measures have been take to protect and promote equal rights there is still much work that can be done. Although 'legislation at the national and also the state level requires equal treatment and non-discriminatory access in a range of areas including employment, education, access to buildings, public transport and access to government services and information' (Ozdowski, 2004) this is not always reflected in practical terms at all locations. In many countries where similar strong legislation does not exist there can be real issues with access and inclusion for people with disability and their capacity to make significant improvements must be taken into consideration during the Olympic bid process. As the history of the Paralympics has shown, the nature of understanding disability and accessibility has changed over time place and culture.

The Accessibility Guide (International Paralympic Committee, 2013, p23) identifies a narrower focus of potential beneficiaries of planning for an accessible and inclusive environment than Darcy and Dickson (2009). These include: people who use wheelchairs; people who have a mobility impairment; people who have a visual impairment; people who are hard of hearing; people with an intellectual impairment; people who have a psychological impairment; and other groups. When these considerations are seen in context to the group dynamics visiting venues, events or the games cities this constitutes a considerable number of people identified as the constituents of the games and includes: host city residents, tourists, games participants; Olympic/Paralympics families, VIPs, officials; employees; media; volunteers; subcontractors; and spectators. Figure 1 identifies the seven phases of what the IPC have identified as the equitable games experiences for all constituents (International Paralympic Committee, 2013, p25). This approach to the stages of recreation or travel has a reflective dimension (Clawson \& Knetsch, 1966) and others have referred to this as the whole of journey experience (Zuniga, Bunker, \& Bevrani, 2013). The journey activities begin with the information search on websites or through other official sources for the constituents involved. Once the requisite games information has been obtained, then trip planning begins through bookings, reservations and (where appropriate) these/customs. For those participating purchasing tickets or accreditation procedures must be finalised before undertaking travel that may have a local, regional, national or international dimension. This process has been underexplored in the literature with recent studies beginning to incorporate a more nuanced understanding of whole of journey experience (Dickson, Darcy, Johns, \& Pentifallo, in press; Dickson, Misener, et al., in press). While attending the 
games may be the 'main course' for most, experiencing the ambience of the host city through the five senses of sight, hearing, smell, taste and touch creates memorable experiences for all those attending (Small \& Darcy, 2011; Small, Darcy, \& Packer, 2012). When a games is truly memorable for the constituents involved the whole host city experiences "psychic benefits” (Davis, 2012; Humphreys \& Prokopowicz, 2007). The psychic benefit effect is said to be even more powerful with the Paralympics (Cashman \& Darcy, 2008). Figure 1 has been adapted to include the journey home and reflecting on the experience (Clawson \& Knetsch, 1966), where from the Paralympic perspective people without disability experience engaging with disability sport has been anecdotally described as a transformative experience by the IPC and others. However, the empirical evidence required to support these assertions has not been adequately addressed (Cashman \& Darcy, 2008).

\section{Figure 1: Games Constituents’ Activities and Experiences}

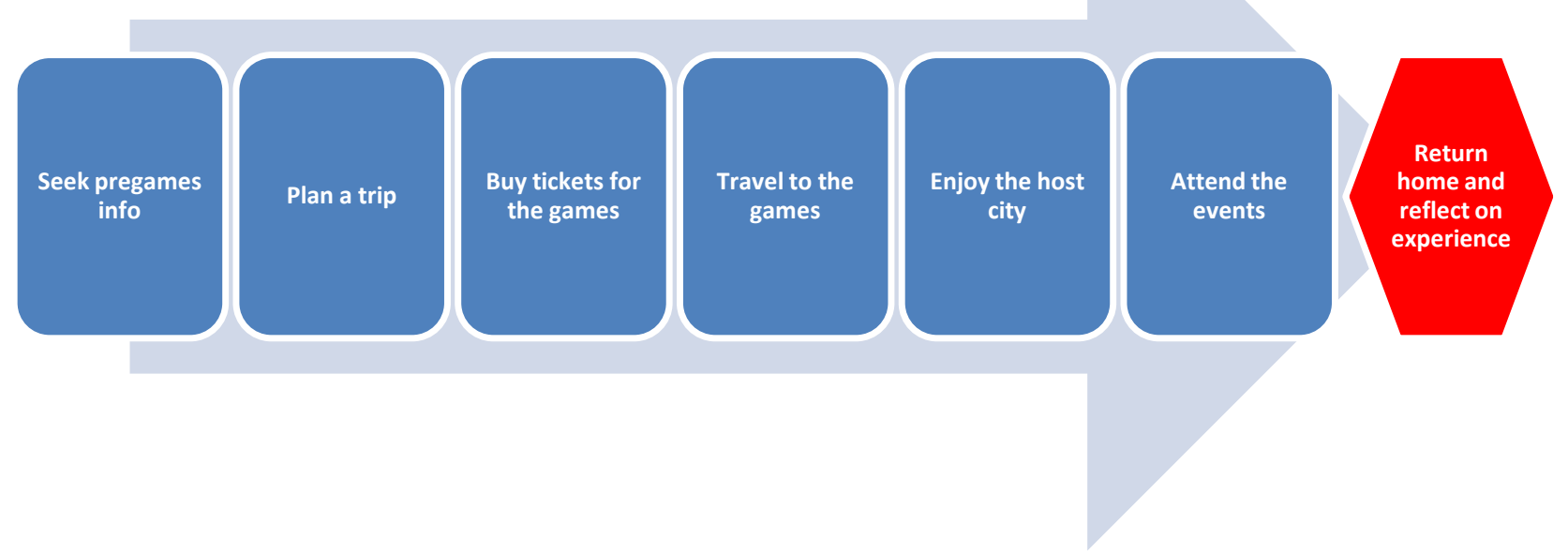

Source: adapted from International Paralympic Committee Accessibility Guide (2013)

\section{VENUES AND THE VILLAGE}

Venue accessibility requires a coherent understanding of the accessibility guidelines that are underpinned by “adaptable and universal design” (International Paralympic Committee, 2009, 2013. While definitions are provided, the underlying philosophy is that the guidelines should be guide by universal design and internationally accepted best practice seeking to achieve outcomes used by people of all functional abilities. Applying the principles of universal design can be seen as a way of developing Olympic and Paralympic environments, transportation, services and offers, underpinning sustainable communities and businesses (Fleck, 2015). See the following references for detailed considerations of developing an accessible Paralympic Village (Beasley, 1996; Laski, 2009; Paterson, 2012; Sainsbury, 1997, 2008) and sports facilities (Beasley, 1998; Beasley \& Davies, 2001; Kung \& Taylor, 2014; Mahoney \& McMillen, 2014; Paramio-Salcines \& Kitchin, 2013; Paramio \& Buraimo, 
2013). A key binding element is an accessible path of travel for people with mobility, vision, hearing and cognitive disabilities that should not contain impediments to be negotiated by the group. The key considerations for an accessible path of travel include:

- $\quad$ access and circulation

- $\quad$ amenities

- $\quad$ publication and communication

\section{Access and Circulation}

Framed predominantly around mobility and vision considerations access and circulation involves nine key areas: pathways and circulation areas; ramps; stairways; surfaces, paving and finishes; furniture and other services; entrances and exits; doors and always; lifts and elevators; and emergency provisions. For there to be equitable, dignified and functional accessible paths of travel are key understanding of pathways and circulation areas are the dimensions for wheelchair and pedestrian access widths. While it is not possible to go into the detail for all venues, amenity, communications and hotel considerations, the building blocks for mobility and vision circulation spaces are now briefly discussed.

Figure 2 presents the circulation requirements on pathways for individual wheelchair users, a pedestrian and a wheelchair user and to wheelchair users. For the lowest level of compliance, a minimum accessible path of travel needs to be $1000 \mathrm{~mm}$ for a single wheelchair user, $1500 \mathrm{~mm}$ for an ambulant pedestrian and a wheelchair user, or $1800 \mathrm{~mm}$ (AS1428.1-2009 for a minimum length of 2M - Standards Australia, 2009) 2 wheelchair to comfortably pass each other. Further, for a wheelchair to pivot and turn in its own circumference requires a circulation space of $1500 \mathrm{~mm}$ (AS1428.1-2009 requires 1540mm - Standards Australia, 2009). This basic building block needs to be incorporated into Olympic and Paralympic venue, the village and transport interfaces for all routes to be regarded as providing an accessible paths of travel. Of course this building block needs to then take into account the technical information for wheelchair turning circles, requirements for ramps, surfaces, furniture and other services, entrance and exits and emergency provisions (see pp31-60).

Figure 2: Access Widths
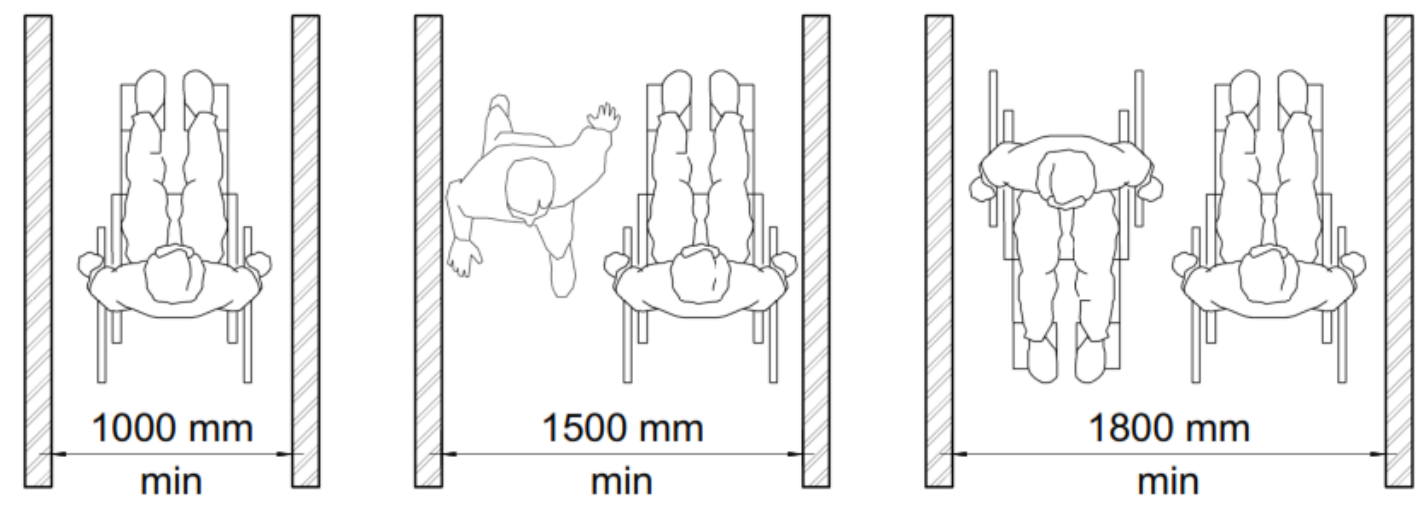
Similarly for those with vision impairment the emphasis moves from circulation to understanding elimination of trip hazards and protruding objects. As Figure 3 shows for people who are blind or are vision impairment, that clear pathways of travel includes headway of a height from $700 \mathrm{~mm}$ - $2100 \mathrm{~mm}$, and $400 \mathrm{~mm}$ (AS1428.1-2009 requires a clear space of 1000x2000 see (Standards Australia, 2009) into the pedestrian pathways including corridors, aisles and passageways. This includes all landscaping materials, signage and other fixtures, which all must be of high contrast. Further, once the infrastructure is in place operational managers must also be aware not to put temporary signage or portable furniture within these spaces.

\section{Figure 3: Limits of Protruding objects for people with a Vision Impairment}

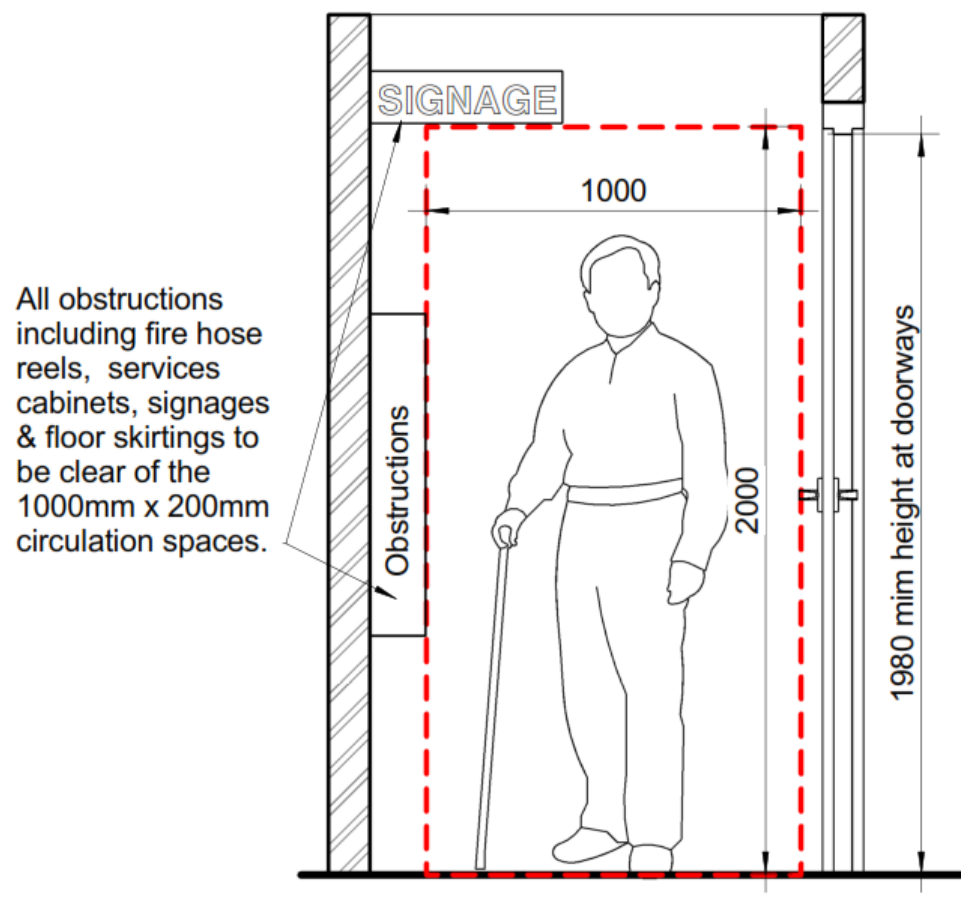

Source: Farah Madon, Vista Access Architects (C) 2016

\section{Amenities}

Amenities include venue seating, washrooms, and baths, showers and change rooms. Venue seating of any Sport event requires $0.50 \%$ of seating to be accessible whereas for the Olympic context a higher $0.75 \%$ and Paralympic $1.20 \%$ of gross venue seating capacity is required to accommodate increased number of spectators with access requirements. Of this seating there should be availability across different areas, viewing ranges and ticket types. As outlined in Figure 4 the mobility seating should include a space of:

- $800 \mathrm{~mm}$ by $1300 \mathrm{~mm}$ for wheelchair users; 


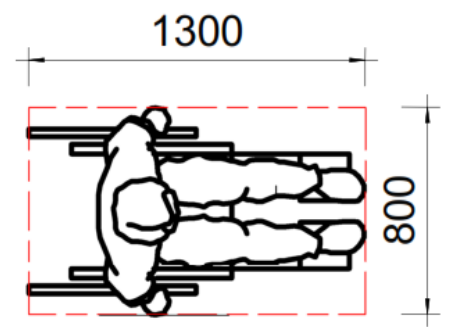

\section{A90 footprint}

\section{Source: Farah Madon, Vista Access Architects (C) 2016}

- $500 \mathrm{~mm}$ by $1300 \mathrm{~mm}$ for companion or enhanced amenity seating; and

- $1000 \mathrm{~mm}$ of circulation space behind the seating for easy access and egress. (See diagram below that demonstrates the requirements as per AS1428.1-2009 - Standards Australia, 2009)

\section{Figure 4: Stadium seating diagram}

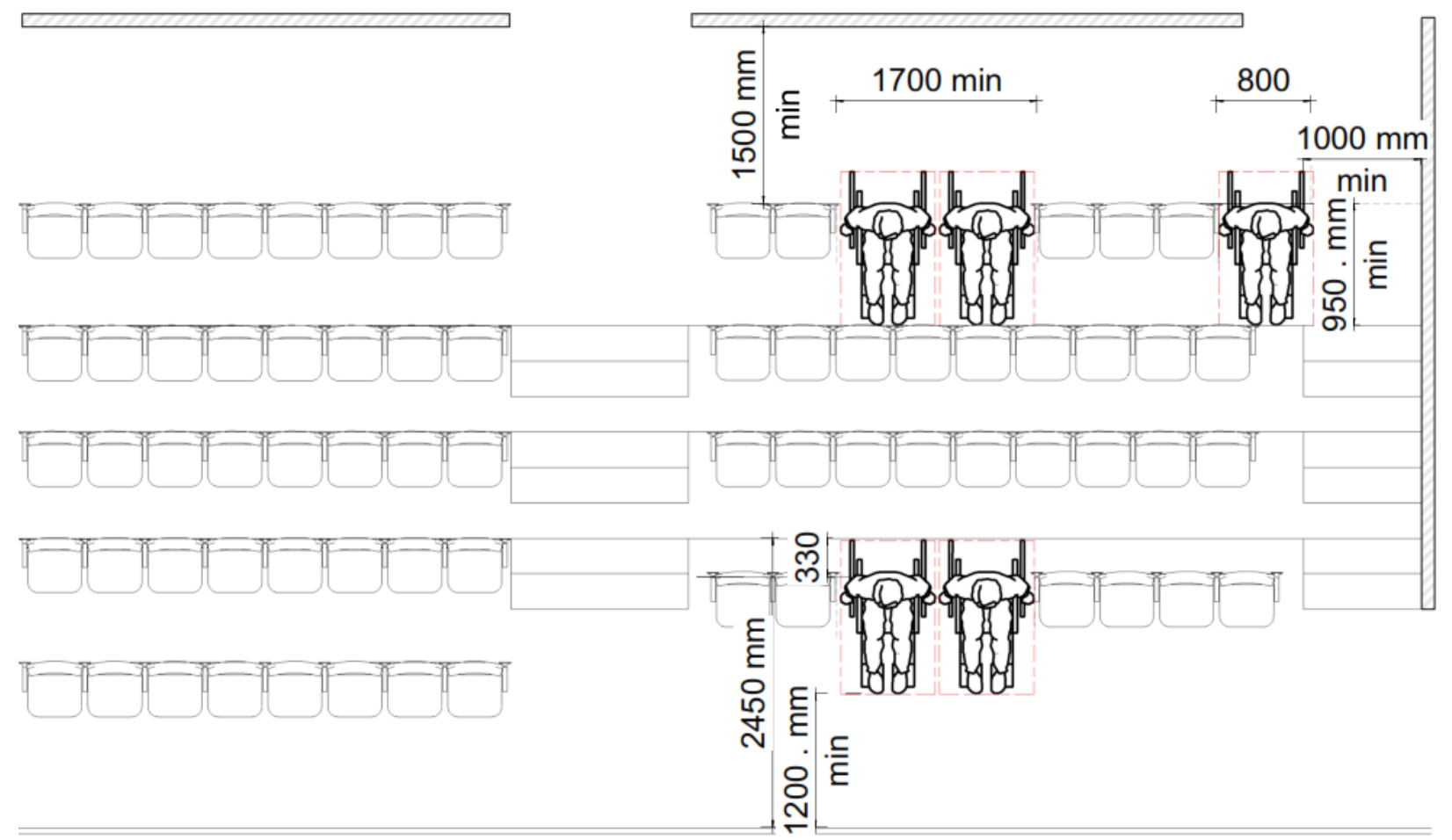

Source: Farah Madon, Vista Access Architects (C) 2016

\section{Amenities}

Photo $1 \& 2$ provides an example of integrated seating at the Sydney Olympic Stadium Australia that was based on the Olympic Coordination Authority access guidelines (Olympic Coordination Authority, 1999). As the photo shows, when mobility access is considered from the beginning the seating is not only well integrated but provides excellent sightlines and anonymity for 
mobility spectators. However, for people with vision or hearing impairments, other forms of information and communication augmentation needs to be considered. For people who are vision impaired or are blind, wayfinding through the provision of tactile ground surface indicators, Braille or raised a letter signage and audio described spectators services create a more equitable, dignified and functional experience. In particular, audio described sport spectating services have become main stream through the provision of "sports ears" (http://www.sportsears.com.au/shop/) and other services that literally describe field of play action for the general public and people who are blind or vision impaired becoming beneficiaries of mainstream enhance sport description services. Similarly people who are deaf or hearing impaired benefit from hearing augmentation services that provide systems (e.g. t-switches) that connect to those with hearing aids or enhanced visual signage or live captioning of sport commentating. Of course, for major speeches sign language interpretation services are also provided. The performing arts have been leading the field when it comes to inclusive audience experiences and the following references provide examples (Sydney Opera House, 2015, 2016; Whitfield \& Fels, 2013)

Photo 1: $\quad$ Integrated wheelchair seating and tactile ground surface indicators at Stadium Australia, the main stadium for the Sydney 2000 Olympic Stadium

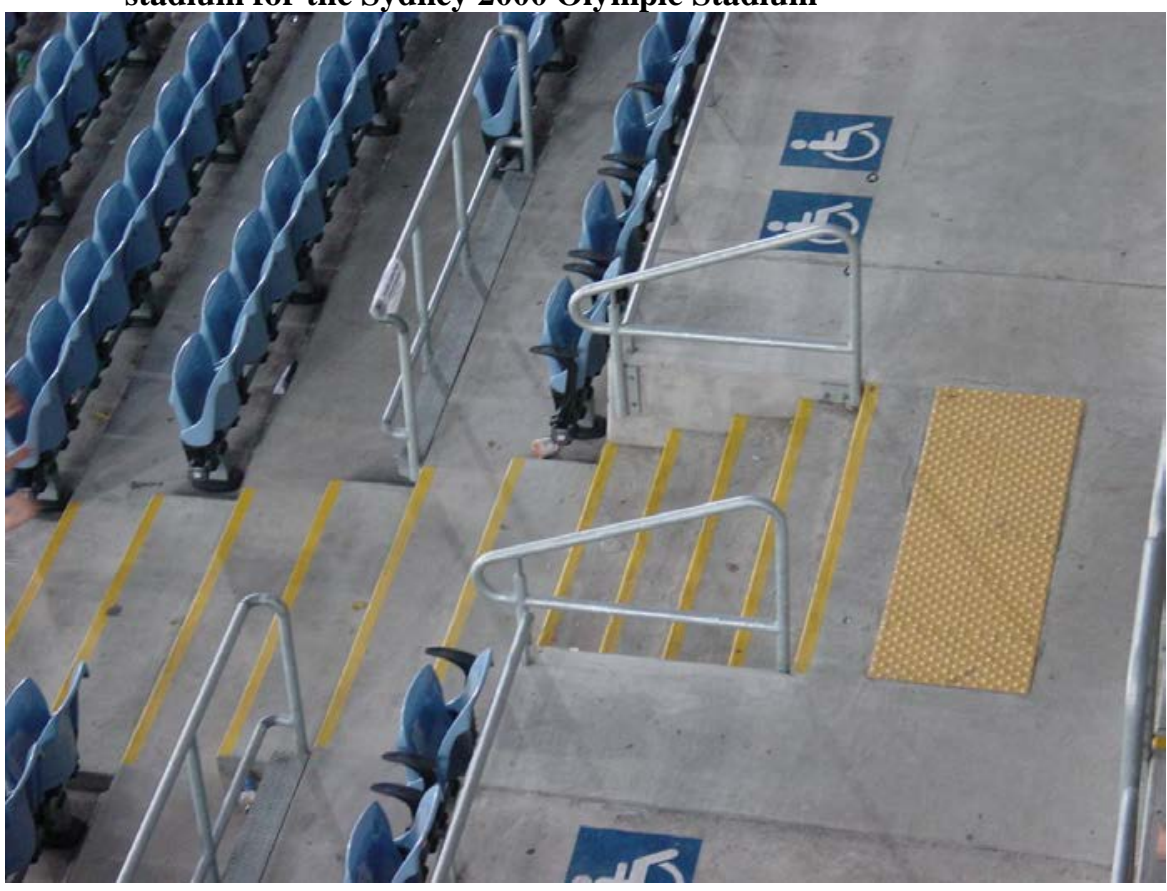

Source: (C) Fiona Darcy 2000 


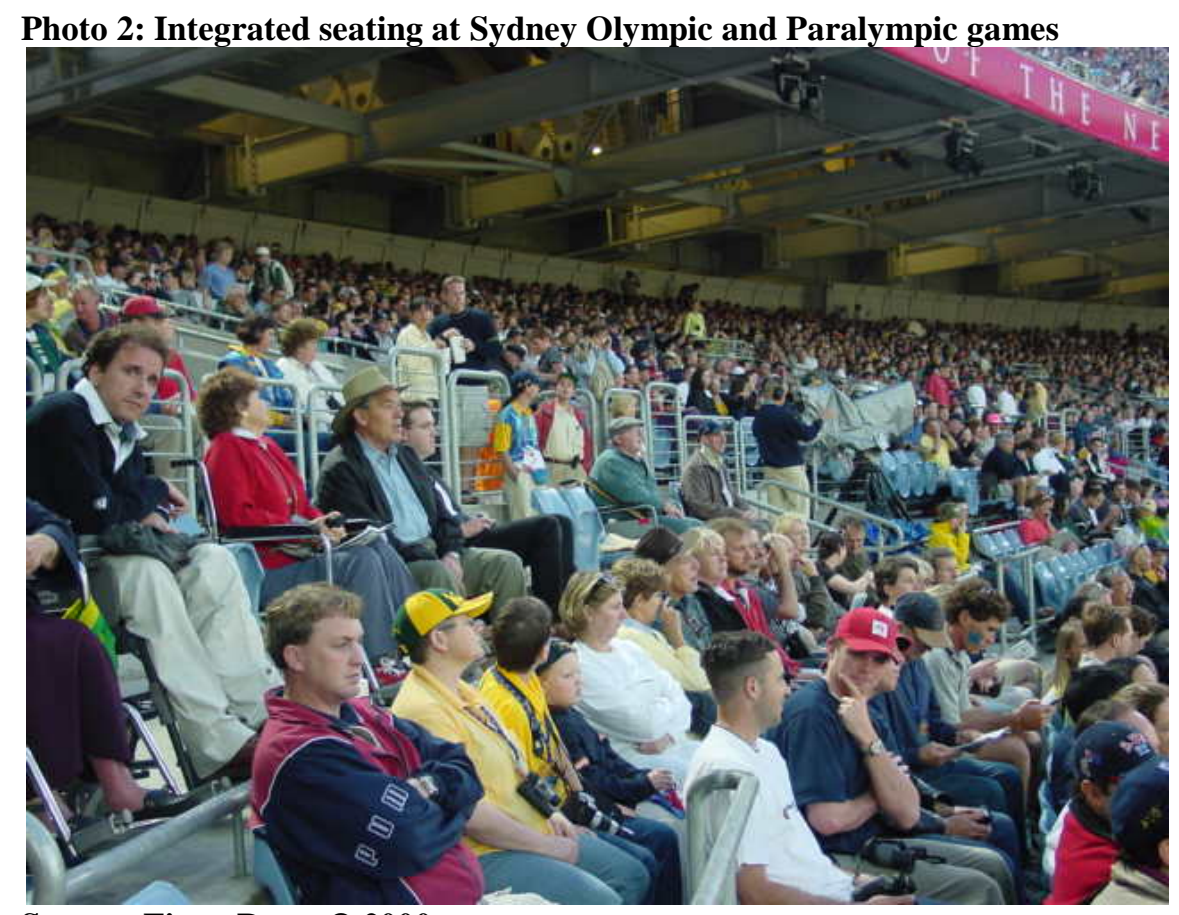

Source: Fiona Darcy@ 2000

As one would expect, for participants and spectators alike the provision of accessible bathrooms, showers and change rooms is essential for an accessible games experience. The gold standard are for accessible bathrooms, showers and change rooms to be uni sex to allow for carer or attendant support from people of the opposite sex if required. The location and provision of such facility should be in the same general location is that of the standard public access washroom and identified by universal iconography and wayfinding signage. The ratio should be the same as gender specific toilets with one per bank of gender specific toilets in public areas. As Figure 5shows the configurations for a left-hand transfer accessible toilet and shower. 
Figure 5: Uni Sex Left-Hand Transfer Accessible Toilet and Shower

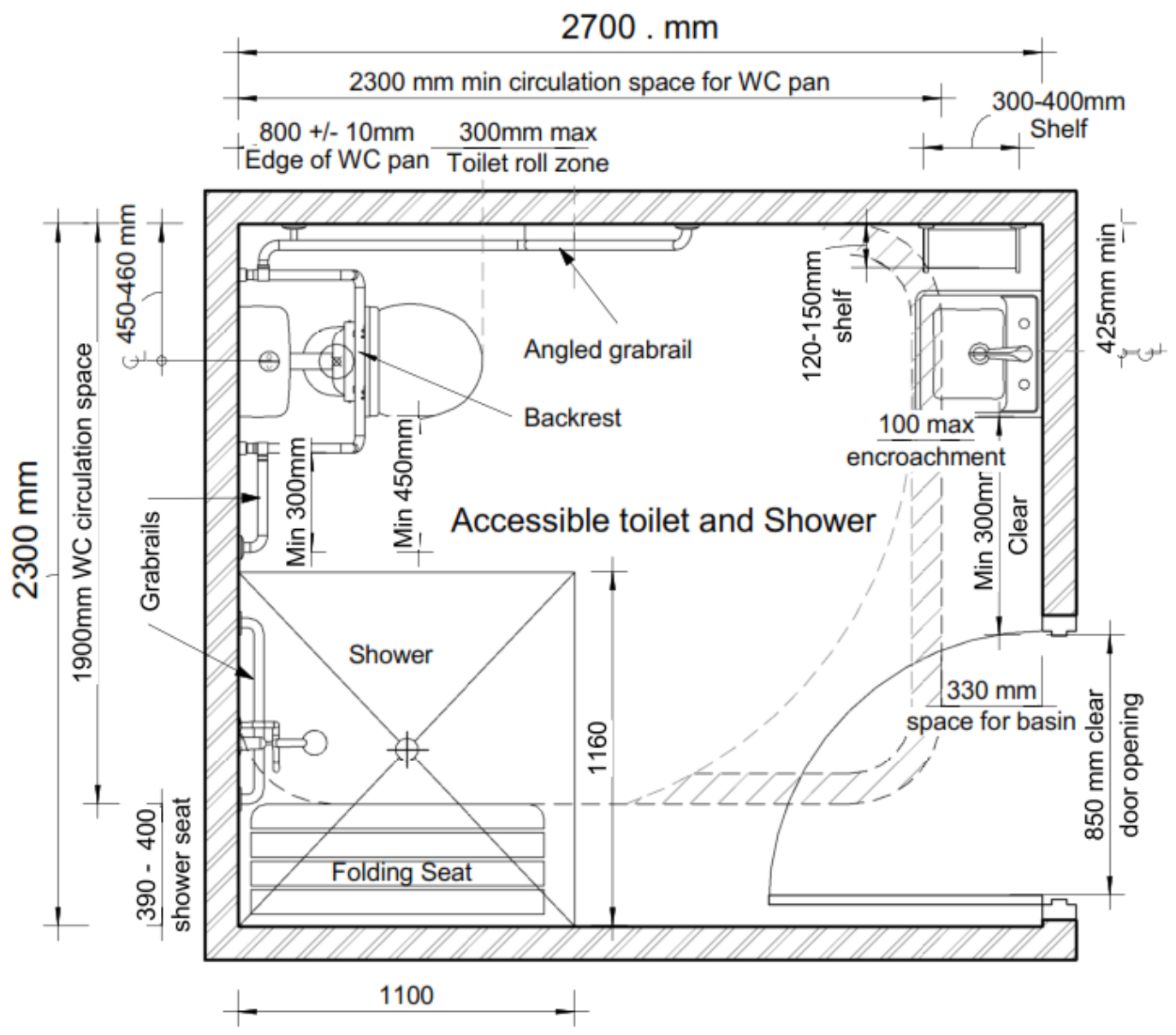

Source: Farah Madon, Vista Access Architects (C) 2016

As far all other ticket, merchandising and concession outlets there should be provision for independent wayfinding, signage and access to counters (see Figure 6). For example, any concession stand for food and beverages should have provisions for wheelchair users with a lowered height counter consisting of $750 \mathrm{~mm}$ underside clearance to a depth of $500 \mathrm{~mm}$ and between $850-900 \mathrm{~mm}$ in height (see Standards Australia, 2009). Further, all staff should be provided with disability awareness training for customer service provision for people with mobility, vision, hearing and cognitive disabilities. This should be part of a considered customer service program to be inclusive of paid employees, subcontractors and volunteers. The outcome will be a better informed workforce who are confident in the correct etiquette of offering assistance across these access groups (Dept for Public Works \& Pensions \& Dept of Media \& Culture 2015 ). 
Figure 6: Accessible Service Counter

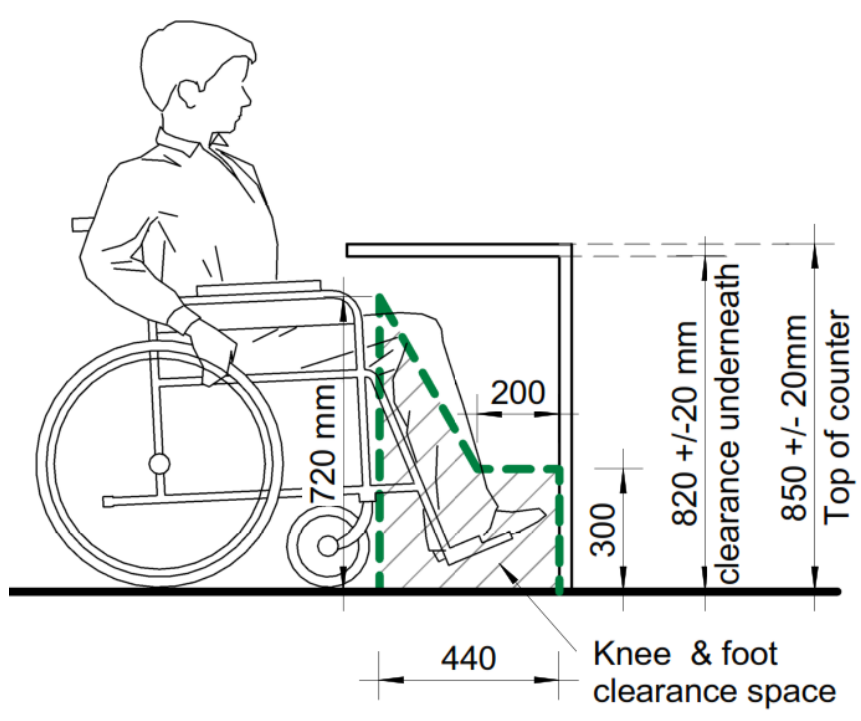

Source: Farah Madon, Vista Access Architects @ 2016

\section{Publications, Alternative Formats, Communication and Wayfinding}

Of course, no games can be truly accessible without providing clear communication through OCOG publications, websites and wayfinding systems for all those involved in attending the games. For many, their only experience of the games will be through watching on television but even for this group the provision of games information through the publications and websites is critical. This is particularly so for those who are vision impaired or blind, those with hearing impairments or deaf, or those with intellectual or cognitive disability. With print publications considerations of contrast, type colour, point size, other formatting, number of columns and design simplicity can improve accessibility for people with disability. The provision of accessible websites to W3C compliance (Chisholm \& Vanderheiden, 1999) has been well established since the Sydney 2000 Olympic and Paralympic games where Bruce McGuire, a blind man, took, two federal court actions against the SOCOG because of the lack of accessibility of its ticket book (no Braille alternative format) and its website not being accessible to screen readers use by people who are blind ("Maguire v SOCOG [HREOCA H 99/115]," 2000a; "Maguire v SOCOG [HREOCA H 99/115]," 2000b). Other alternative formats in Braille, plain or easy English, audio recordings, electronic documents or captioned video or live captioning are but some of the alternative forms of communication to provide accessibility for people with disability (for more information see Media Access Australia, 2015).

As with all major events, telecommunication plays a major role in internal and external communication processes. With respect to people with disability, the availability of public telephones that have inclusions for wheelchair access and also the availability of telephone typewriters (TTY) for people who are deaf or hearing impaired is essential. Further, the provision of FM hearing loops, passive infrared emitters, captioning and sign language interpretation are all provisions that will assist those with hearing impairment or who are deaf. As the nature of communication has changed, access 
to wireless Internet and Internet cafes is essential. As per the requirements of continuous pathways discussed earlier in the chapter, Internet cafe should have provisions for mobility access and also all computer terminal should be equipped with screen readers for people who are blind, magnifying windows for those who have vision impairments, speech to text for people with dexterity issues, and adapted keyboards/mice again for those with dexterity issues. The area of telecommunications accessibility has been described as an area of “digital divide” for some people with disability not just because of the disabling nature of the technology but also because of limited access due to social economic disadvantage (Alper, Ellcessor, Ellis, \& Goggin, 2015; Goggin \& Newell, 2003).

The environment of the host city, together with the Olympic and Paralympic precincts also need to consider broader wayfinding considerations for people who have mobility, vision or hearing disability (Darcy, 2012b; Gill, 2009). The IPC outline the importance of signage that makes use of clearly marked pictograms, directional indicators and other devices that not only point out the important features for people with disability but also those without the language of the host city. Accessible signage additionally adds an understanding of where people with mobility disability can find accessible pathways. This becomes critical in crowded environments during major games events. While the international symbols of accessibility for mobility, hearing and vision are well-known there are also a host of other iconography they can be effectively used for more efficient wayfinding. The IPC accessibility guide specifies the major elements of signage including the location, symbol sizes, letter sizes and provide specific examples. As Photo 3 identifies, signage is not only functional because also form part of the branding of any event through being able to dress disparate venues with a common overlay.

Photo 3 \& 4: Signage at Sydney 2000 Olympic and Paralympic Games

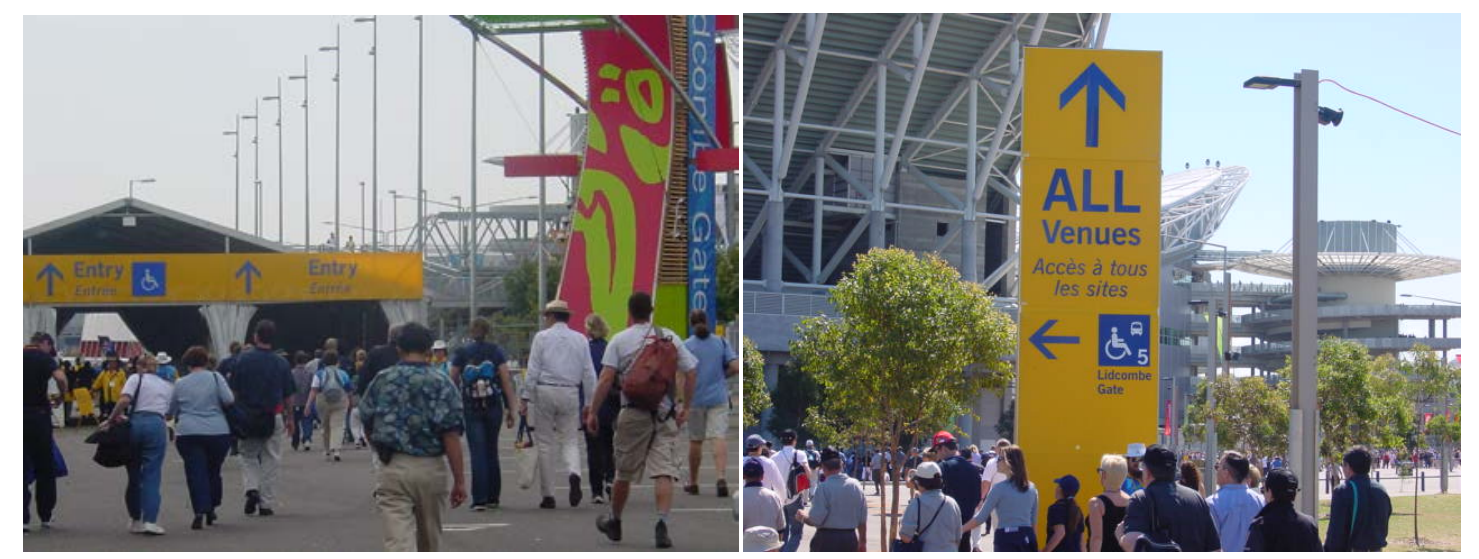

Source: $\odot$ Fiona Darcy 2000

Source: (C) Fiona Darcy 2000

\section{TRANSPORT}

It is said that any city that wins the Olympic bid will succeed or fail on the success of its transport systems (Kassens-Noor, 2012). The IPC recognised that for all stakeholders with access needs, an integrated transport system is the "single most important aspect for creating an inclusive 
urban environment” (IPC Accessibility Guide, 2013 p90). Quite simply if the transport system fails all stakeholders including athletes, officials, employees, volunteers and spectators will be unable to have any games experience. In context to the Paralympic games the overlay of accessibility on the transportation systems and processes requires all those with access needs to travel from all the different countries from around the world participating via air transport, road, rail and maritime using public and private providers. Yet, very few papers have examined the success of Paralympic transport systems (Darcy, 2003; Hendy, 2013). The UN and the World Bank examine the importance of such frameworks to citizenship and while not overtly making the connection or extending the concept of an "accessible Path of travel” or the "whole of journey experience”, the 'travel chain' as a concept (World Health Organization \& World Bank, 2011) is immensely simple yet operationally difficult to achieve in urban environments where the infrastructure and systems are not in place to achieve what is defined as:

'all elements that make up a journey, from starting point to destination — including the pedestrian access, the vehicles, and the transfer points. If any link is inaccessible, the entire trip becomes difficult' (World Health Organization \& World Bank, 2011, p. 179).

The IPC Accessibility Guidelines go on to identify specific inclusive practice across the following transportation means: roads; rail; air; and maritime. As with all aspects of accessibility, transport accessibility must be considered with respect to predominantly mobility, vision and intellectual impairments, but are also inclusive of those who are deaf or hearing impaired as many people with disability have multiple disabilities. The individual transportation means each have technical and performance measures outlined. Each of these will briefly be discussed in context to servicing people with disability in getting to Olympic and Paralympic games host cities, and participating, working/volunteering or spectating at the games.

\section{Road transport}

Road transport incorporates the cars and taxis, coaches, public buses, transport stops, parking areas and signage for accessible parking. While the predominance of transport for all stakeholder groups with disabilities is provided by public or chartered buses, the Paralympic games makes use of cars, minivans and taxis that are wheelchair accessible. While many wheelchair users are able to independently transfer from their wheelchair into a car or bus seat, many are unable to due to their impairment. For cars, minivans and taxis use for point to point transfer of people with mobility disability, they recommend vehicles with side or rear access to allow wheelchair users to remain in their mobility aids, have a passenger seat that provides ease of access, and provide integrated seating for companions, teammates or officials travelling with wheelchair users. Vehicles may be equipped with external hoists, rear loading ramp or side loading ramps to allow access and egress. The IPC have specified main technical measurements for accessible vehicles as outlined in Table \#: 
Table \#Key Technical Requirements for accessible vehicles:

\begin{tabular}{lr}
\hline \multicolumn{1}{c}{ Component } & Measurement \\
\hline & \\
\hline Internal clearance height & $1500 \mathrm{~mm}$ \\
Doorway width & $800 \mathrm{~mm}$ \\
Loading platform length & $1300 \mathrm{~mm}$ \\
Loading platform width & $800 \mathrm{~mm}$ \\
Weight operation & $200 \mathrm{~kg}$ \\
Loading time & $<60$ seconds \\
Active and passive restraint systems & recommended \\
\hline
\end{tabular}

Source: adapted from IPC Accessibility Guidelines (2013, p92)

Similarly any coaches used for the Paralympics should provide loading ramps for wheelchair users to independently access and stay in their wheelchairs. Loading ramps should take people directly to the position on the coach where wheelchair seating and lockdowns are provided. Public buses should be provided or contracted, that provide a low floor chassis together with a 'kneeling” function to reduce the gradient of the access and egress ramp, and provide wheelchair spaces for those who prefer to stay in their wheelchairs. Within the Olympic and Paralympic village, contracted public buses in the low floor area should remove all seating to facilitate multiple wheelchair loading.

Within car parks used for the Olympics and Paralympics, a minimum of $2 \%$ and best practice of $3 \%$ of car spaces should be set aside for accessible parking and the clearly signposted. Accessible parking bays should be at least 1.5 times the size of the standard parking space with a minimum of 3.2 $\mathrm{m}$ and best practice of $3.6 \mathrm{~m}$. Accessible parking bay should be level or not more than 1:50 (2\% gradient) with underground parking providing a minimum of $2.3 \mathrm{~m}$ or best practice of $2.5 \mathrm{~m}$ to ensure roof mounted wheelchair vehicles can operate without hindrance. The location of accessible parking should be within proximity to pedestrian entries and exits, lifts and ramps, accessible toilets and pay stations. For all road transport infrastructure to access the urban environment is required such as shade/shelter, curb height of $150 \mathrm{~mm}$, curb ramps of no more than 1:8 gradient, tactile ground surface indicators indicating hazards and directions $300 \mathrm{~mm}$ from the curb edge, curbs linking vehicle drop off areas to accessible pathways, lighting, signposting and rest seating should be provided.

\section{Rail}

Rail considerations include both heavy and light rail or tram provisions. While cities like Sydney and Rio de Janeiro provided extensions to heavy rail lines, most Olympic and Paralympic transport operates within the provisions of currently constructed systems. The Paralympics provides an opportunity for upgrading rail network provisions. When Sydney was awarded the Olympic games, only $8 \%$ of rail stations were easy access accessible. The extension to the rail network to Sydney Olympic Park provided the opportunity to construct a network of best practice from a mobility, vision and hearing perspective. Some 16 years later while all rolling stock have provision for accessibility, approximately $20 \%$ of rail stations are easy access accessible showing the lead time required to 
upgrade rail stations not built with access considerations. With respect to people who are blind or vision impaired, the importance of tactile ground surface indicators for independent access cannot be understated. These indicators provide notice of danger and also provide direction for an accessible Path of travel. When used in conjunction with clear audio announcements on stations and in carriages, people with vision impairment can be provided with an equality of rail travel experience. For people who are deaf or hearing impaired, clear signage indicators and scrolling text are essential for the provision of information. A series of technical inclusions are provided for accessible stations, accessible carriages and other provisions (IPC, 2013, p9-96).

\section{Air transport}

Air transport has been one of those areas where the Paralympics has pushed innovation in order to achieve transport success first and foremost for athletes and officials. Tokyo 1964 became the first Olympic and Paralympic city to benefit from innovation in transport where in order to get UK competitors to Tokyo, the Stoke Mandeville GOC negotiated with airlines on transporting athletes to the game led to a technological breakthrough in an "aisle chair" (International Paralympic Committee, 2015c). Ever since this breakthrough the aisle chair has become synonymous with regional and international travel for people with mobility disability and has led to a safer work environment for thousands of airline employees.

The travel planning, access, on-board experience and egress, have challenged people with disability and their service providers alike (Darcy, 2012a; Van Horn \& Isola, 2014). Many National Paralympic Committees broker special chartered services for transporting Paralympic athletes to and from Paralympic competition. For example, Qantas have a special chartered jet to take the Australian Paralympic team to Rio in 2016. Qantas engineers and the Australian Paralympic Committee have been working on customised seating for athletes with specific mobility disability to ensure the most comfortable flight so athletes arrive in as good a shape as possible to participate (Shalala, 2015). Further as Qantas states, “the Australian Paralympic committee works with Qantas to deliver best practice systems to ensure our customers along with their equipment arrived safely and ready to achieve their best” (Qantas, 2016).

The Olympics and Paralympics offer an opportunity for destinations to upgrade their airports and airport procedures to be more accommodating of people with disability. The IPC guidelines identify the following areas at airports and with airlines as areas to work on for Paralympic preparation: parking areas; parking ticket validation machine; drop-off zones; ticket checking counters; terminal energy; information/communication systems; security screening; embarking/disembarking; airport gate; aisle chair; staff awareness; storage of aids; seating; access of guide dogs; and hoists. The other area of consideration for disability is with respect to safety provisions and the need to provide passenger briefing cards in alternative formats for people who are 
blind or vision impaired, deaf or hearing impaired or have cognitive disabilities that require easy English or other communication approaches.

While the IPC access guidelines outline important considerations for airports and airlines, but a great deal of these responsibilities lie with individual airlines and the way that airport servicing of people with disability are dealt with in destination areas. To achieve better outcomes across these areas, the IPC and the OGOCs work in conjunction with organisations like Open Doors to deliver airport and airline training to improve services for people with disability (Lipp, 2015). The importance of these provisions cannot be understated as anyone with higher mobility support needs may have two hours longer in an airport and an hour longer on aeroplanes than any other travellers simply because they are required to be at the airport earlier, board the plane first and disembark the plane last. Even when airline processes are working perfectly this is a significant extra burden on the athlete or spectator with disability.

\section{Maritime}

Depending upon the location of the Olympics and Paralympics, maritime access may play a significant or strategic role transport systems. In the same way as road, rail and air transport, there are a series of considerations for a seamless accessible path of travel. These include: parking; ticket sales; terminal access; information/communication; infrastructure required; access to vessels; alternative format provisions; vessel amenities; and passenger seating. While there are a great deal of similarities with previous means of transportation discussed, some types of vessel, infrastructure provisions and access to vessels require a brief discussion. Public ferries in most large cities have some form of access for people with mobility needs. However, smaller charter vessels that are used in some Paralympic context for transporting VIPs and others to maritime based events or special events may prove problematic from a mobility access perspective. Cruise ships have become more accommodating of people with disability (depending upon geographic market area they serve and the relative effectiveness of disabilities discrimination) but some ports can only be accessed by 'tenders' that are generally not accessible for wheelchair users. Depending upon the part of the world that the Paralympics are in, there is a great deal of variation in tides that create issues for access to vessels and access to ports for people with mobility access requirements. Engineering solutions include floating pontoon wharves that vary with tidal movements, gangway and ramp systems for ferries that provide easy access embarking and disembarking; with larger cruise ships employing "air bridge” system is similar to airlines to allow an accessible path of travel without steps. Depending upon the size of the vessel, once on board all standard access requirements discussed in this chapter apply.

\section{WHOLE OF DESTINATION APPROACHES TO ACCESSIBILITY}

The IPC Accessibility Guidelines (2009; 2013) sought to boundary cross from the confines of the Olympic and Paralympic venues and precincts, to bring a whole of destination approach to 
accessibility. In doing so, the IPC sought to leverage a greater understanding of the businesses, destinations and networks, that are required to create liveable communities and provide opportunities for future business development through accessible tourism for people with mobility, vision, hearing, cognitive and sensitivity disability. The games are said to bring forward urban development by 30 years in a truncated planning, development and operations of the games precincts into a nine year period (Darcy \& Taylor, 2013; Gold \& Gold, 2010). Understanding markets with access needs also fits with the recent developments of the UN World Tourism Organisation's push to see the development of accessible destinations and experiences. The UN WTO has moved from encouraging change to delivering frameworks and resources through its Global Code for Ethics in Tourism (1999) and the five volume Manuals on Accessible Tourism (European Network for Accessible Tourism, 2015; UNWTO, 2015a, 2015b, 2015c, 2015d, 2015e, 2015f). As suggested by the UNWTO publications and other contemporary research, destinations are at a competitive advantage by being inclusive of the $31 \%$ of the population that benefit from disability and accessibility inclusions (Dickson, Misener, et al., in press; Domínguez, Darcy, \& Alén, 2015).

\section{Hotels}

As early as Sydney 2000, the IPC recognised significant issues with the accessibility of hotel accommodation in host cities (Darcy, 2001, 2003). As late as one month before the Sydney 2000 Paralympic games, the Sydney Paralympic Organising Committee through the Olympic Coordination Authority had to audit the contracted Paralympic hotel, provide recommendations about those membesrs of the Paralympic family requiring accessible accommodation and the shortfall in supply that the hotel offered (Darcy, 2000). To accommodate those members of the Paralympic family requiring accessible accommodation three further hotels had to be contracted to bolster the supply of accessible rooms. To prevent this type of situation occurring again, the IPC has invested in educating the local hotel community on the requirements for Paralympic family and visitors with disability generally. For Rio 2016 for example, the IPC Academy ran a one-day workshop for Rio de Janeiro hoteliers outlining global research in the area, best practice in knowledge management for hotel room accessibility, and the business case for preparing for the accessible tourism market visiting Rio for the games (Darcy, 2010, 2011, 2013; International Paralympic Committee Academy, 2013).

The Accessibility Guidelines explicitly set out the requirements for "wheelchair friendly" accessible guestrooms. Apart from the standard mobility access provisions already outlined, as Figure 6 shows the importance of circulation space in both the bedroom and bathroom is critical. The other key requirement for an accessible guestroom for people with mobility disability is the provisions for bathrooms. As there are different cultural contexts for the preference of bathtubs or roll in showers, the guidelines stipulate that even numbers of bathtubs and roll in showers should be provided in each establishment. While a great deal of the provisions in accessible guestrooms has to do with mobility, 
there are some important considerations for people who are blind/vision impaired or Deaf/hearing impaired. For people with vision impairment overall lighting should be maintained at a minimum of 30 lux, with lighting is at counters and sinks being 70 lux. Further, clocks are required to have a large high contrast display. For people with hearing impairments, telephones need to be compatible with hearing aids, have a message light that flashes and rooms need to have both visual and audible alarms. While the guidelines for "wheelchair friendly" and accessible guestrooms are a major step forward for many parts of the world, best practice would suggest a much wider turning circle for power wheelchairs (2250mm as opposed to the $1550 \mathrm{~mm}$ in the IPC guidelines) and a host of other inclusions for other impairment groups as shown in Figure 7 (Madon \& Relf, 2016).

\section{Figure 7: Accessible Guest Room Floorplan}

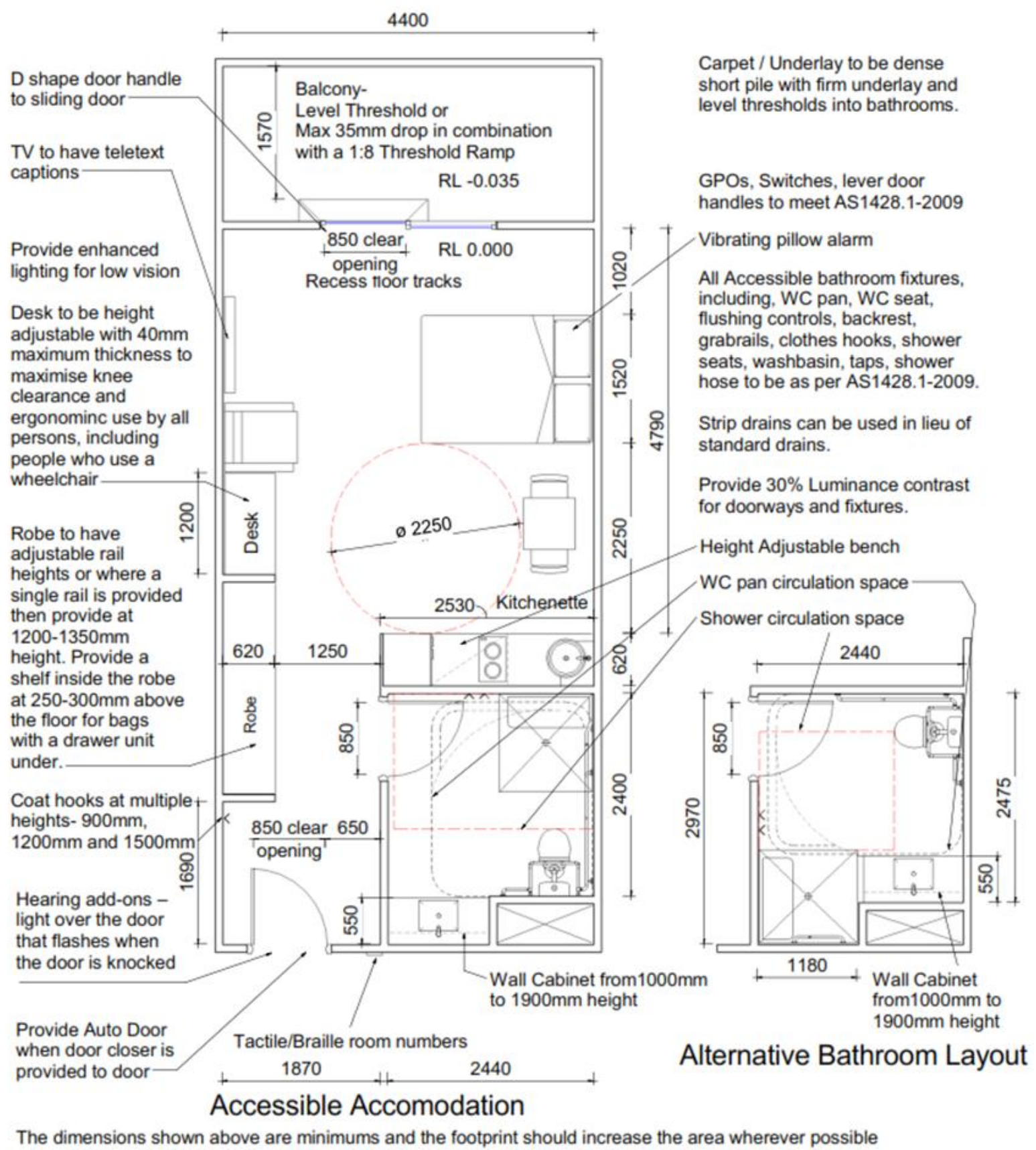

Source: Farah Madon, Vista Access Architects (C) 2016 


\section{TRAINING FOR ACCESSIBILITY AND DISABILITY AWARENESS}

A chapter of the accessibility guide is devoted to training for accessibility. It focuses on disability awareness training, games/job specific training on accessibility and venue specific training on accessibility. The focus of the training is for the games workforce including volunteers to be prepared to provide a first-class experience for athletes and spectators with disability. The program seeks to enhance customer service training "to demystify issue of disability for all customer facing staff" and "must furnish participants with the tools and confidence to transfer basic disability awareness and etiquette knowledge to their roles" (IPC 2013, p105). Importantly, the manual notes that the training must also take into account cultural appropriateness. In a refreshingly inclusive approach, the scope of the training recognises that all staff will have some contact with members of the public, elite athletes or co-workers with disability. A review of disability awareness training literature (Lindsay \& Edwards, 2013) identifies aspects of best practice that the guidelines have adopted and cover the following areas:

- person first approaches to disability;

- attitudes to disability beyond pity and inspiration;

- disability types and support needs;

- communication;

- interpersonal interactions;

- $\quad$ active listening; \&

- $\quad$ etiquette for assisting people with disability;

One of the most vaunted claims by the IPC is that the Paralympic games are major changes of attitude by the general public towards people with disability. However, while anecdotal accounts of attitude change exist there still has not been a systematic approach to testing the attitudes of the general public towards people with disability within a host city. In fact, some early work suggested that disability sport awareness program interventions in schools had no lasting impact on attitude change (Wilhite, Muschett, Goldenberg, \& Trader, 1997). Although more recent programs examining the attitudes of nondisabled students towards students with disabilities in integrated physical education classes after watching Paralympic intervention videos showed a positive change in attitude (McKay, Block, \& Park, 2015). There have been some more recent studies that suggest there may be short-term attitude change but these studies tend to rely on single intervention and are based on student or University cohorts as the test subjects rather than the general public (Ferrara, Burns, \& Mills, 2015). Similarly, while still relying on single interventions, a German experimental design study sought to examine the effects of different levels of empathy on audience interests, attitudes and behavioural intentions. The differing levels of empathy were 'elevation and reflective thoughts' and 'feeling of closeness, elevation and pity’ (Bartsch, Oliver, Nitsch, \& Scherr, 2016). The area of attitude change 
and the Paralympics is ripe for work within future host cities particularly when considering the effect of the cultural context on attitudes towards people with disability.

\section{CASE STUDY - EVIDENCE FROM LONDON 2012}

Misener, Darcy, Legg, and Gilbert (2013) provides empirical research evidence of improving disability infrastructure in the host city. However, they acknowledge that while it is possible to plan for access in new Olympic infrastructure - including venues, transport and public spaces around venues - the wider city environment often poses challenges. While the legacy from London 2012 are beginning to emerge (legacy requires time!) access both venues and transport can benefit greatly with the London Games said to have 'set the standard' for future Paralympics games and made the host city significantly more accessible (Bamford, 2016; Bamford \& Dehe, 2016; McNevin, 2014; Naish \& Mason, 2014; Sumner, 2012a, 2012b; Waboso, 2014). Yet, there are cautionary notes about the extent beyond the games precincts, volunteer experiences sport participation generally, and removing transport barriers, where the soft legacy considerations of the material improvement of people with disabilities’ independence remain largely unchanged (Ahmed, 2013; Bamford \& Dehe, 2016; Brittain, 2016; Bush, Silk, Porter, \& Howe, 2013; Christiansen, 2013; Darcy, Dickson, \& Benson, 2014; Evans, 2015, p. p.32; Grey-Thompson, 2013). Bamford (2016) raises concerns that 'the momentum toward further improvements is waning'. This Olympic and Paralympic games accessibility experience of international attention where both the OCOGs and government have the short-term political will to be wanting to be lauded for their efforts dissipates soon after the games ends and was similar to Sydney 2000 (Darcy, 2001, 2003, 2016; Darcy \& Appleby, 2011). The IPC (2009a; 2013) have been visionary in wanting the Paralympic games to be a change maker for the disability community in host destinations and those visiting. Yet, as Baroness Grey-Thompson, a former Paralympian and a cross-bench peer in the House of Lords, suggests that the London 2012 Paralympic legacy is 'slipping away' because the social care support system is losing funding. She also states that it is difficult for society to change its attitude to social inclusion and access when people with disabilities are not able to access the support they need to undertake day to day activities. 'But if you can't get out of bed or get washed in the morning, then you can't change the way people think, you can't take part in sport and you are not going to be involved in the community' (Grey-Thompson, 2013).

\section{CONCLUSION}

One of the most significant differences between the Olympics and the Paralympics is the importance of accessibility. This chapter has reviewed the major considerations from the IPC Accessibility Guide (2009a; 2013) together with contemporary research practice and reviews. Given 
the lack of consistent standards for accessibility across the world, the IPC initiative has provided leadership for bidding cities and subsequently awarded host cities as to a common language of what is to be expected from one games to the next. Disability and accessibility is an ongoing dynamic development of expectations across impairment types and levels of support needs. As time progresses, so do the expectations of people with disability and the IPC need to ensure that the accessibility guidelines are constantly updated as world best practice moves forward. While guidelines do not guarantee implementation, the evidence from London 2012, and the guidelines from Rio 2016 suggest that efforts being made by the IPC are paying dividends. Yet, as noted in the London 2012 case study, legacy is always determined by the ongoing impact and the change in the material position of people with disability in the host city and country, that require an ongoing commitment to improving the human rights position of people with disability as stipulated by the UN CRPWD. 


\section{REFERENCES}

Ahmed, N. (2013). Paralympics 2012 legacy: accessible housing and disability equality or inequality? Disability \& Society, 28(1), 129-133.

Alper, M., Ellcessor, E., Ellis, K., \& Goggin, G. (2015). Reimagining the Good Life with Disability: Communication, New Technology, and Humane Connections. In H. H. Wang (Ed.), Communication and the "Good Life" (pp. 197-212). New York: International Communication Association Theme Book Series, vol 2 - Peter Lang.

Bamford, D. (2016). Lessons from London: how hosting the Paralympics can make cities more accessible. The Conversation. Retrieved from The Conversation website: https://theconversation.com/lessons-from-london-how-hosting-the-paralympics-can-makecities-more-accessible-53044

Bamford, D., \& Dehe, B. (2016). Service quality at the London 2012 games - a paralympics athletes survey. International Journal of Quality \& Reliability Management, 33(2), 142-159.

Bartsch, A., Oliver, M. B., Nitsch, C., \& Scherr, S. (2016). Inspired by the Paralympics: Effects of Empathy on Audience Interest in Para-Sports and on the Destigmatization of Persons With Disabilities. Communication Research.

Beasley, K. A. (1996). The Paralympic Village: a barrier-free city. Olympic Villages: A Hundred Years of Urban Planning and Shared Experiences: International Symposium on Olympic Villages. Lausanna, 105-108.

Beasley, K. A. (1998). Fields of dreams: today's newest sports facilities provide accessibility that people with disabilities at one time could only with for. Sports ' $n$ spokes, 24(5), 10-14.

Beasley, K. A., \& Davies, T. D. (2001). Chapter 47 - Access to Sport and Entertainment. In W. F. E. Preiser \& E. Ostroff (Eds.), Universal Design Handbook (pp. 47.41-48.41). New York: McGraw-Hill.

Blackman, D., Dickson, T. J., \& Benson, A. M. (2016). Enabling volunteer legacies: a knowledge management perspective. Event Management, Accepted 6 April 2016, all.

Brittain, I. (2010). The Paralympic Games explained. Milton Park, Abingdon, Oxon ; New York: Routledge.

Brittain, I. (2016). A Critical Perspective on the Legacy of the London 2012 Paralympic Games. Journal of the Nippon Foundation Paralympic Research, 4(2), 23-42.

Bush, A., Silk, M., Porter, J., \& Howe, P. D. (2013). Disability [sport] and discourse: stories within the Paralympic legacy. Reflective Practice, 14(5), 632-647.

Cashman, R., \& Darcy, S. (Eds.). (2008). Benchmark Games: The Sydney 2000 Paralympic Games. Petersham, NSW Australia: Walla Walla Press in conjunction with the Australian Centre for Olympic Studies.

Center for Universal Design. (2009). Universal Design Principles Retrieved 20 May, 2009, from http://www.design.ncsu.edu/cud/about_ud/about_ud.htm

Chisholm, W., \& Vanderheiden, G. (1999). Web Content Accessibility Guidelines 1.0 Retrieved 22nd May, 2016

Christiansen, S. (2013). A year after the Paralympics attitudes to disability need to improve. The Guardian,. Retrieved from The Guardian, website: http://www.theguardian.com/sport/blog/2013/aug/24/paralympics-sophie-christiansenequestrian

Clawson, M., \& Knetsch, J. L. (1966). The Economics of Outdoor Recreation. Baltimore: Johns Hopkins Press.

Darcy, S. (2000). The Paralympic Family Hotel - The Wentworth Hotel Access Audit. Sydney: report to Olympic Co-ordination Authority.

Darcy, S. (2001). A Games for Everyone?: Planning for Disability and Access at the Sydney 2000 Games. Disability Studies Quarterly, 21(3).

Darcy, S. (2003). The politics of disability and access: the Sydney 2000 Games experience. Disability \& Society, 18(6), 737-757. 
Darcy, S. (2010). Inherent complexity: Disability, accessible tourism and accommodation information preferences. Tourism Management, 31(6), 816-826.

Darcy, S. (2011). Developing Sustainable Approaches to Accessible Accommodation Information Provision: A Foundation for Strategic Knowledge Management. Tourism Recreation Research, 36(2), 141-157.

Darcy, S. (2012a). (Dis)Embodied Air Travel Experiences: Disability, Discrimination and the Affect of a Discontinuous Air Travel Chain. Journal of Hospitality and Tourism Management, 19(e8 August), 1-11.

Darcy, S. (2012b). Disability, Access, and Inclusion in the Event Industry: A Call for Inclusive Event Research. Event Management, 16(3), 259-265.

Darcy, S. (2013). Keynote address: Accessible Tourism, Accessible Hotels and the Business Case. Paper presented at the IPC Academy - Rio 2016 excellence program, Rio de Janeiro, Brazil. http://eng.spbu.ru/

Darcy, S. (2016). Paralympic Legacy - Learning from the Sydney 2000 to prepare for Tokyo 2020. Journal of the Nippon Foundation Paralympic Research, 4(1), 43-61.

Darcy, S., \& Appleby, L. (2011). Sydney 2000: Moving from Post-Hoc Legacy to Strategic Vision and Operational Partnership. In D. Legg \& K. Gilbert (Eds.), Paralympic Legacies (pp. 75-98). Champaign, IL USA: Common Ground Publishing LLC.

Darcy, S., \& Dickson, T. (2009). A Whole-of-Life Approach to Tourism: The Case for Accessible Tourism Experiences. Journal of Hospitality and Tourism Management, 16(1), 32-44.

Darcy, S., Dickson, T. J., \& Benson, A. M. (2014). London 2012 Olympic and Paralympic Games: Including Volunteers with Disabilities - A Podium Performance? Event Management, 18(4), 431-446.

Darcy, S., Frawley, S., \& Adair, D. (2016). The Paralympic Games: Managerial ad Stratgic Dimensions. In S. Darcy, S. Frawley \& D. Adair (Eds.), Managing the Paralympics (pp. 1-20). Basingstoke, Hampshire: Palgrave Macmillan.

Darcy, S., \& Harris, R. (2003). Inclusive and accessible special event planning: an Australia perspective. Event Management, 8(1), 516-536.

Darcy, S., \& Taylor, T. (2009). Disability citizenship: An Australian human rights analysis of the cultural industries. Leisure Studies, 28(4), 419-441.

Darcy, S., \& Taylor, T. (2013). Managing Olympic Venues. In S. Frawley \& D. Adair (Eds.), Managing the Olympics (pp. 99-126). Houndmills, Basingstoke: Palgrave Macmillan.

Davis, J. A. (2012). The Olympic Games effect: How sports marketing builds strong brands: John Wiley \& Sons.

Dept for Public Works \& Pensions, \& Dept of Media \& Culture (2015 ). The inclusive and accessible stadia report. London Dept for Public Works \& Pensions.

Dickson, T. J., Darcy, S., Johns, R., \& Pentifallo, C. (in press). Transformative Service Research and major sport event accessibility. The Services Industry Journal, in press.

Dickson, T. J., Misener, L., \& Darcy, S. (in press). Enhancing destination competitiveness through disability sport event legacies: developing an interdisciplinary typology. International Journal of Contemporary Hospitality Management, 17, Accepted 27 March 2016 2010.1108/IJCHM2010-2015-0530.

Domínguez, T., Darcy, S., \& Alén, E. (2014). Juegos olímpicos y paralímpicos en Brasil: Aprendiendo de Barcelona y Sidney Olympic and Paralympic Games in brazil: Learning from Barcelona and Sydney. RAE-Revista de Administração de Empresas Journal of Business Administration (Brazil Portuguese),, 54(2), 222-230.

Domínguez, T., Darcy, S., \& Alén, E. (2015). Competing for the disability tourism market - a comparative exploration of the factors of accessible tourism competitiveness in Spain and Australia. Tourism Management, 47(1), 261-272.

Dowling, M., \& Legg, D. (2017). Stakeholders and the Paralympic games. In S. Darcy, S. Frawley \& D. Adair (Eds.), Managing the Paralympics (pp. 21-46). Basingstoke, Hampshire: Palgrave Macmillan.

European Network for Accessible Tourism. (2015). Who we are Retrieved 15 August 2015, 2015, from http://www.accessibletourism.org/?i=enat.en.who_we_are 
Evans, G. (2015). Accessibility and user needs: pedestrian mobility and urban design in the UK. Proceedings of the Institution of Civil Engineers - Municipal Engineer, 168(1), 32-44.

Ferrara, K., Burns, J., \& Mills, H. (2015). Public attitudes toward people with intellectual disabilities after viewing Olympic or Paralympic performance. Adapted Physical Activity Quarterly, 32(1), 19-33.

Fleck, J. (2015). Inclusive Design \&\#8211; a lasting Paralympic Legacy? Embedding inclusive design knowledge and skills into architectural education. Charrette, 2(1), 92-105.

Fox, N. (2015). Paralympics 2016: How does Rio cater for disabled people? Retrieved 15/2/16, 2016, from http://www.bbc.com/news/disability-34171951

Gill, J. (2009). The 2012 challenge to help disabled and older people. Safety and Reliability, 29(3), 7476.

Goggin, G., \& Newell, C. (2003). Digital disability: The social construction of disability in new media: Rowman \& Littlefield.

Gold, J. R., \& Gold, M. M. (2007). Access for all: the rise of the Paralympic Games. The Journal of the Royal Society for the Promotion of Health, 127(3), 9.

Gold, J. R., \& Gold, M. M. (2010). Olympic cities: city agendas, planning and the world's games, 1896-2016. London: Taylor \& Francis.

Grey-Thompson, T. (2013). The Paralympic legacy is slipping away. Too many disabled people are being abandoned by the system, The Telegraph. Retrieved from http://www.telegraph.co.uk/news/uknews/10168792/The-Paralympic-legacy-is-slipping-away.Too-many-disabled-people-are-being-abandoned-by-the-system.html

Hendy, S. P. (2013). Papers The outcomes of transport planning for the 2012 Olympic and Paralympic Games. Journal of Urban Regeneration \& Renewal, 7(1), 9-20.

Humphreys, B. R., \& Prokopowicz, S. (2007). Assessing the impact of sports mega-events in transition economies: EURO 2012 in Poland and Ukraine. International Journal of Sport Management and Marketing, 2(5-6), 496-509.

International Olympic Committee. (2011). 2020 Candidature Acceptance Procedure Retrieved from http://www.olympic.org/Documents/Host_city_elections/2020_CAP.pdf

International Paralympic Committee. (2009a). Accessibility Guide: An Inclusive Approach to the Olympic \& Paralympic Games Retrieved from http://www.paralympic.org/IPC/Documentation_Centre/

International Paralympic Committee. (2009b). Paralympic Media Awards 2009 Retrieved from http://www.paralympic.org/IPC/Awards/Paralympic_Media_Awards/Paralympic_Media_Awa rds 2009.html?calendar.box.year $=2010$ \&calendar.box.month $=0$

International Paralympic Committee. (2013a). Accessibility Guide: An Inclusive Approach to the Olympic \& Paralympic Games.

International Paralympic Committee. (2013b). Accessibility Guide: An Inclusive Approach to the Olympic \& Paralympic Games Retrieved from http://www.paralympic.org/IPC/Documentation_Centre/

International Paralympic Committee. (2015a). City of Rio's accessibility improvement plans praised by IPC President Retrieved 12/2/16, 2016, from http://www.paralympics.org/news/city-rio-saccessibility-improvement-plans-praised-ipc-president

International Paralympic Committee. (2015b). PyeongChang 2018 completes the 'Accesibility Manual' Retrieved 12/2/16, from http://www.paralympics.org/news/pyeongchang-2018-completesaccessibility-manual

International Paralympic Committee. (2015c). Tokyo 1964: developing one of the world's best public transport systems Retrieved 18/8, 2015, from http://www.paralympic.org/news/tokyo-1964developing-one-world-s-best-transport-systems\#! prettyPhoto

International Paralympic Committee Academy. (2013). Rio 2016 Excellence Program - Workshop On the Accessible Tourism Market. Bonn: IPC.

Kassens-Noor, E. (2012). Planning Olympic legacies: Transport dreams and urban realities: Routledge.

Kung, S. P., \& Taylor, P. (2014). The use of public sports facilities by the disabled in England. Sport Management Review, 17(1), 8-22. 
Laski, J. (2009). Towards a Greener Olympics: Sustainable Development and the Vancouver 2010 Athletes' Village at Southeast False Creek. Journal of Environmental Law and Practice, 20(1), 37-60.

Legg, D., \& Gilbert, K. (Eds.). (2011). Paralympic Legacies. Champaign, IL USA: Commonground Publishing.

Lindsay, S., \& Edwards, A. (2013). A systematic review of disability awareness interventions for children and youth. Disability and Rehabilitation, 35(8), 623-646.

Lipp, E. (2015). What creates access and inclusion at airports? Journal of Airport Management, 9(4), 390-397.

Mace, R. (1985). Universal Design, Barrier Free Environments for Everyone. Los Angeles, CA: Designers West.

Madon, F., \& Relf, M. (2016). Practice Note: Accessible Accommodation Sydney: Association of Consultants in Access Australia Inc. (in press to be published late 2016).

Maguire v Sydney Organising Committee for the Olympic Games (Internet) [2000] (Human Rights and Equal Opportunity Commission No H 99/115 2000a).

Maguire v Sydney Organising Committee for the Olympic Games (Ticket book) [2000] (Human Rights and Equal Opportunity Commission No H 99/115 2000b).

Mahoney, M. P., \& McMillen, J. D. (2014). Facility Planning, Design, and Management of Mobility Assistance Programs: Review and Recommendations of Accessible Routes From Super Bowl XLV. Journal of Facility Planning, Design, and Management, 2(2).

McKay, C., Block, M., \& Park, J. Y. (2015). The Impact of Paralympic School Day on Student Attitudes Toward Inclusion in Physical Education. Adapted Physical Activity Quarterly, 32(4).

McNevin, N. (2014). London 2012 legacy: principles, purpose, professionals and collaboration. Proceedings of the Institution of Civil Engineers - Civil Engineering, 167(6), 13-18.

Media Access Australia. (2015). Service Providers Accessibility Guide: A quick reference guide for accessible communications. Sydney: Media Access Australia,

Misener, L. (2017). Managing Legacy and the Paralympic Games. In S. Darcy, S. Frawley \& D. Adair (Eds.), Managing the Paralympics (pp. 91-110). Basingstoke, Hampshire: Palgrave Macmillan.

Misener, L., Darcy, S., Legg, D., \& Gilbert, K. (2013). Beyond Olympic Legacy: Understanding Paralympic Legacy through a Thematic Synthesis. Journal of Sport Management, 27(4), 329341.

Motte-Baumvol, B., \& Nassi, C. D. (2012). Immobility in Rio de Janeiro, beyond poverty. Journal of Transport Geography, 24, 67-76.

Naish, C., \& Mason, S. (2014). London 2012 legacy: transformation of the Olympic Park. Proceedings of the Institution of Civil Engineers - Civil Engineering, 167(6), 26-32.

Olympic Co-ordination Authority. (1999). Access Guidelines (3rd ed.). Sydney: Olympic Coordination Authority.

Ozdowski, S. (2004). Preparations for the Olympics and Paralympics and inclusion of people with disabilities: the Australian experience Retrieved 14/2/16, 2016, from https://www.humanrights.gov.au/news/speeches/preparations-olympics-and-paralympics-andinclusion-people-disabilities-australian

Paramio-Salcines, J. L., \& Kitchin, P. J. (2013). Institutional perspectives on the implementation of disability legislation and services for Spectators with Disabilities in European professional football. Sport Management Review, 16(3), 337-348.

Paramio, J. L., \& Buraimo, B. (2013). Promoting accessibility for fans with disabilities to European stadia and arenas. Managing the Business of Sport: An Introduction, 367.

Paterson, N. (2012). BREEAM and the Code for Sustainable Homes on the London 2012 olympic park: lessons from the Velodrome, Aquatics Centre and the Olympic and Paralympic Village: Garston, Watford: BRE Trust.

Peters, D., Frawley, S., \& Favaloro, D. (2017). Leading the Team: The Role of the Chef de Mission at the Paralympic Games. In S. Darcy, S. Frawley \& D. Adair (Eds.), Managing the Paralympics (pp. 173-190). Basingstoke, Hampshire: Palgrave Macmillan. 
Qantas. (2016). Australian Paralympic Committee Retrieved 30 April, 2016, from http://www.qantas.com/travel/airlines/australian-paralympic-commitee/global/en

Rio 2016 Organising Committee. (2014). Rio 2016 Accessibility Technical Guidelines. In Rio 2016 Organising Committee (Ed.).

Rio 2016 Organising Committee. (2015). Rio mayor launches project to improve accessibility in city ahead of 2016 Olympic and Paralympic Games Retrieved 12/2/16, from http://www.rio2016.com/en/news/rio-mayor-launches-project-to-improve-accessibility-in-cityahead-of-2016-olympic-and-paralympi

Rio 2016 Organising Committee for the Olympic and Paralympic Games. (2014). Rio 2016 Accessibility Technical Guidelines: Version 3 (January 2014) Retrieved from http://www.paralympic.org/IPC/Documentation_Centre/

Sainsbury, T. (1997). Athletes at the Paralympic Village. In M. de Moragas, Llin`es and Kidd, B (Eds) (Ed.), Olympic Villages: One Hundred Years of Urban Planning and Shared Experiences (pp. 173-179). Lausanne: International Olympic Committee.

Sainsbury, T. (2008). Chapter 10 - The Paralympic Village. In R. Cashman \& S. Darcy (Eds.), Benchmark Games: The Sydney 2000 Paralympic Games (pp. 181-200). Petersham, NSW Australia: Walla Walla Press in conjunction with the Australian Centre for Olympic Studies.

Santos, A. S., \& Ribeiro, S. K. (2013). The use of sustainability indicators in urban passenger transport during the decision-making process: the case of Rio de Janeiro, Brazil. Current Opinion in Environmental Sustainability, 5(2), 251-260.

Shalala, A. (2015, 15 September 2015). Australia's Paralympian to benefit from more comfortable flight seating for Rio games travel, $A B C$ online. Retrieved from http://www.abc.net.au/news/2015-09-16/measures-taken-to-improve-comfort-for-australiasparalympians/6780876

Small, J., \& Darcy, S. (2011). Chapter 5 - Understanding Tourist Experience Through Embodiment: The Contribution of Critical Tourism and Disability Studies. In D. Buhalis \& S. Darcy (Eds.), Accessible Tourism: Concepts and Issues (pp. 72-96). Bristol, UK: Channel View Publications.

Small, J., Darcy, S., \& Packer, T. (2012). The embodied tourist experiences of people with vision impairment: Management implications beyond the visual gaze. Tourism Management, 33(4), 941-950.

Sochi 2014 Organizing Committee. (2014). Barrier-Free Environment at the Sochi 2014 Olympic and Paralympic Games. Sochi: Sochi 2014 Organising Committee.

Standards Australia. (2009). AS 1428.1 Design for access and mobility - General requirements for access - New building work with amendments (4th ed.). Homebush, NSW: Standards Australia.

Sumner, H. (2012a). Briefing: Delivering London 2012: Meeting the transport challenge. Proceedings of the Institution of Civil Engineers - Transport, 165(4), 237-239.

Sumner, H. (2012b). Delivering London 2012: Transport legacy. Proceedings of the Institution of Civil Engineers - Transport, 165(4), 267-275.

Sydney Opera House. (2015). Access Guide. Sydney: Sydney Opera House.

Sydney Opera House. (2016). Sydney Opera House Access Strategic Plan 2016-18. Sydney: Sydney Opera House.

Szwarcwald, C. L., Andrade, C. L. T. d., \& Bastos, F. I. (2002). Income inequality, residential poverty clustering and infant mortality: a study in Rio de Janeiro, Brazil. Social Science \& Medicine, 55(12), 2083-2092.

United Nations. (2006). Convention on the Rights of Persons with Disabilities. New York: http://www.un.org/disabilities/convention/conventionfull.shtml: United Nations General Assembly A/61/611 - 6 December 2006.

United Nations World Tourism Organization. (1999). Global Code of Ethics for Tourism Retrieved $21 \mathrm{Feb}, 2010$, from http://ethics.unwto.org/en/content/global-code-ethics-tourism

UNWTO. (2015a). Manual on Accessible Tourism for All: Principles, Tools and Good Practices Module 1 Retrieved from http://www.e-unwto.org/doi/book/10.18111/9789284416486

UNWTO. (2015b). Manual on Accessible Tourism for All: Principles, Tools and Good Practices Module 2 Retrieved from http://www.e-unwto.org/doi/abs/10.18111/9789284416509 
UNWTO. (2015c). Manual on Accessible Tourism for All: Principles, Tools and Good Practices Module 3 Retrieved from http://www.e-unwto.org/doi/book/10.18111/9789284416523

UNWTO. (2015d). Manual on Accessible Tourism for All: Principles, Tools and Good Practices Module 4 Retrieved from http://www.e-unwto.org/doi/abs/10.18111/9789284416547

UNWTO. (2015e). Manual on Accessible Tourism for All: Principles, Tools and Good Practices Module 5 Retrieved from http://www.e-unwto.org/doi/pdf/10.18111/9789284416585

UNWTO. (2015f). Manual on Accessible Tourism for All: Public-private Partnerships and Good Practices Retrieved from http://www.e-unwto.org/doi/pdf/10.18111/9789284416585

Van Horn, L., \& Isola, J. A. (2014). Toward a global history of inclusive travel. Review of Disability Studies: An International Journal, 2(2).

Waboso, D. (2014). London 2012 legacy: putting London Underground on a new track. Proceedings of the Institution of Civil Engineers - Civil Engineering, 167(6), 53-60.

Whitfield, M., \& Fels, D. I. (2013). Inclusive Design, Audio Description and Diversity of Theatre Experiences. The Design Journal, 16(2), 219-238.

Wilhite, B., Muschett, C. A., Goldenberg, L., \& Trader, B. R. (1997). Promoting inclusive sport and leisure participation: evaluation of the Paralympic Day in the Schools model. Adapted physical activity quarterly, 14(2), 131-146.

World Health Organization, \& World Bank. (2011). World Report on Disability, from http://www.who.int/disabilities/world_report/2011/report/en/index.html

Zuniga, K., Bunker, J., \& Bevrani, K. (2013). Intraurban Rail Access. Transportation Research Record: Journal of the Transportation Research Board, 2351, 38-45. 